BOMBARDI, Larissa Mies.

O Bairro Reforma Agrária e o Processo de Territorialização Camponesa.

São Paulo: Annablume, 2004. 395p.

\title{
TERRITORI ALI ZAÇÃO CAMPONESA NO ESTADO DE SÃO PAULO: UM ESTUDO DO BAIRRO REFORMA AGRÁRIA
}

\author{
Júlio César Suzuki *
}

O Bairro Reforma Agrária e o Processo de Territorialização Camponesa ${ }^{1}$, de Larissa Mies Bombardi, não é somente mais um livro sobre a reforma agrária, é um estudo sobre a primeira experiência concreta brasileira de reforma agrária, realizada, no início da década de 1960, a partir da Lei de Revisão Agrária, sancionada pelo Governo do estado de São Paulo.

O processo se estabelece com a desapropriação de, aproximadamente, metade da Fazenda Capivari, decadente produtora de café, em Campinas, e o estabelecimento do assentamento Núcleo Agrário Capivari, com 72 lotes, adquiridos por meio da compra, sobretudo, por produtores camponeses que, em regime de parceria, já trabalhavam na região em outras decadentes fazendas de café.

Após mais de 40 anos do início da experiência, quase $40 \%$ das primeiras famílias assentadas, ainda, permanecem nas terras que se transformaram em um bairro rural, em que a densidade das relações sociais estabelecidas entre os moradores permitiu substituir o nome oficial (Núcleo Agrário Capivari) por outro (Bairro Reforma Agrária) que marca a história dos sujeitos históricos que o constituíram: os produtores camponeses.
São os dilemas, as expectativas, as possibilidades, as utopias e as realizações dos moradores do Bairro Reforma Agrária que Larissa Mies Bombardi reencontra em sua pesquisa de campo e faz impregnar as páginas de seu texto. Trabalho fundado em uma perspectiva qualitativa, sobretudo na história oral, valeu-se do discurso dos seus interlocutores para que não se maculasse uma experiência tão rica de conformação de um território camponês em um dos centros mais dinâmicos do capitalismo no Brasil: a área compreendida entre as cidades de São Paulo e Campinas, à margem da rodovia Bandeirantes.

É uma pesquisa que se introduz no difícil debate sobre as possibilidades de reprodução do trabalho camponês no modo de produção capitalista, fazendo uma opção muito clara da permanência do campesinato como classe social de dentro do capitalismo e não como resíduo que tende ao desaparecimento, tal qual as trilhas já construídas por T. Shanin, José de Souza Martins e Ariovaldo Umbelino de Oliveira.

É este fundamento teórico que alicerça o livro que ora se apresenta, resultado de um extenso trabalho de pesquisa que se inicia, ainda, no terceiro ano de graduação da autora,

\footnotetext{
* Professor Doutor lotado no Departamento de Geografia da Faculdade de Filosofia, Letras e Ciências Humanas da Universidade de São Paulo. Graduado, em Geografia, pela Universidade Federal de Mato Grosso, e, em Letras, pela Universidade Federal do Paraná, com Mestrado e Doutorado, em Geografia Humana, pela Faculdade de Filosofia, Letras e Ciências Humanas da Universidade de São Paulo.
} 
em 1993, constituindo a base de sua monografia de Bacharelado em Geografia e de sua dissertação de mestrado em Geografia Humana, ambas defendidas na Universidade de São Paulo, em 1995 e 2001, respectivamente. A duração desta pesquisa não é mais o tempo de realização das pesquisas de pós-graduação das universidades brasileiras, mas foi aquele que a autora considerou fundamental para nos brindar com o seu denso estudo sobre a produção de um bairro rural em projeto de reforma agrária no estado de São Paulo.

É, aqui, oportuno salientar que a pesquisa revelou-nos faces novas do que se define como bairro rural, sobretudo no que concerne à autonomia do uso do tempo e do espaço pelas famílias camponesas, avançando a partir das contribuições de Maria Isaura Pereira de Queiroz e Liliana Laganá.

Outra contribuição da autora encontrase no aprofundamento do debate acerca da relação entre o campo e a cidade, sobretudo ao valorizar, além da produção - perspectiva que já se tornou uma tradição nos estudos sobre campesinato -, a circulação como um momento relevante da reprodução dos produtores camponeses; em última instância, uma das determinações do sucesso na territorialização camponesa no Bairro Reforma Agrária, sobretudo ao salientar a importância, principalmente, dos mercados de Campinas e São Paulo para a manutenção da produção realizada no assentamento.
O texto, ainda, é extremamente oportuno por seu detalhamento na descrição dos passos seguidos na pesquisa de campo. O cuidado chega a conformar como que uma série fotográfica das atitudes da pesquisadora, do que foi tomado como relevante para se transformar em dado para a análise, do que era dúvida e foi se transformando em certeza.

O Bairro Reforma Agrária e o Processo de Territorialização Camponesa não é, também, somente uma análise das dificuldades e dos obstáculos da realização da reforma agrária, mas é, principalmente, a demonstração de suas possibilidades e viabilidade como instrumento de uma outra inclusão social àqueles alijados de uma reprodução humana marcada pela dignidade.

Assim, seu trabalho não se destina apenas aos pesquisadores em Geografia Agrária, mas a todos aqueles que se interessem em aprofundar uma reflexão sobre os dilemas da reprodução das famílias camponesas no Brasil, os projetos de reforma agrária, a pesquisa de campo nos estudos agrários, a relação entre o campo e a cidade, o desenvolvimento agrário e rural e, principalmente, a sociedade brasileira, com todas as suas contradições e acumulações, ou seja, é um livro para geógrafos, sociólogos, antropólogos, historiadores, economistas.

Pela clareza na exposição das idéias, o livro é, ainda, extremamente recomendado aos pesquisadores em formação: os alunos de graduação.

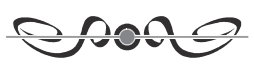

